\title{
MELATIH KEPERCAYAAN DIRI SISWA DALAM MENYATAKAN TANGGAPAN DAN SARAN SEDERHANA MELALUI PENGUATAN PUJIAN PADA PEMBELAJARAN BAHASA INDONESIA
}

\author{
Mariam Magdalena \\ Sekolah Dasar Negeri 133 Seluma \\ mariam2018@gmail.com
}

Submit, 13-06-2018 Accepted,27-06-2018 Publish,29-06-2018

\begin{abstract}
ABSTRAK
Tujuan penulisan ini mendeskripsikan kegiatan dan model pembelajaran bahasa Indonesia di SD Negeri 133 Seluma pada materi memberikan tanggapan dan saran sederhana. Metode penelitian adalah studi pustaka dengan memanfaatkan pegetahuan dan pengalaman mengajar di kelas IV SD Negeri 133 Seluma. Dimana penelitian ini menggambarkan dari hasil pengamatan yang ada di sekolah dasar negeri Seluma. Hasil penelitian menunjukkan bahwa pemberian hadiah dan pujian merupakan reward atau penghargaan atas perilaku baik yang dilakukan anak. Dalam poses pembelajaran di sekolah banyak faktor yang mempengaruhi proses dan hasil pembelajaran yaitu faktor internal dan eksternal. Dalam pembelajaran bahasa Indonesia di SD kelas IV ada materi meyampaikan pendapat sanggahan ataupun saran. Dari pengamatan peneliti menunjukkan bahwa siswa sering malu-malu (tidak percaya diri) dalam menyampaikan pendapat ataupun sanggahan. Dengan memberikan penguatan berupa reward melalui bentuk pujian akan melatih anak untuk akti belajar dan siswa mampu menyampaikan pendapat ataupun sanggahan dengan bahasa yang efektif. Berdasarkan pengalaman penulis dalam memberikan pembelajaran di kelas IV, siswa sangat bersemangat jika pembelajaran dikemas dengan semenarik mungkin. Peneliti mengemas pembelajaran menyenangkan dengan pemberian penghargaan melalui reward ucapan langsung atau penguatan verbal ataupun non verbal di kelas IV SD Negeri 133 Seluma.
\end{abstract}

Kata Kunci: Tanggapan, Penguatan, Pujian, Pembelajaran.

\section{ABSTRACT}

The purpose of this paper describes the activities and models of Indonesian language learning in SD Negeri 133 Seluma on the material provide simple responses and suggestions. The research method is literature study by using knowledge and teaching experience in class IV SD Negeri 133 Seluma. Where this research illustrates from the observations that exist in the Seluma state primary schools. The results show that gift giving and praise are rewards or rewards for good behavior by children. In the poses of learning in schools many factors that affect the process and learning outcomes are internal and external factors. In the learning of Indonesian in elementary school class $I V$ there is the material meyampaikan opinion rebuttal or suggestion. From the observation of the researcher shows that students are often shy (not confident) in expressing opinions or rebuttal. By providing reinforcement in the form of rewards through the form of praise will train the child to active learning and students are able to express opinions or arguments with an effective language. Based on the experience of the authors in providing learning in class $I V$, students are very excited if the learning is 
packed with as attractive as possible. Researchers packed fun learning by awarding rewards through direct speech or verbal or non verbal reinforcement in fourth grade SD Negeri 133 Seluma.

Keywords: Response, Reinforcement, Praise, Learning.

\section{PENDAHULUAN}

Menurut Undang-Undang Sistem Pendidikan Nasional Nomor 20 Tahun 2003 menjelaskan bahwa: "Pendidikan nasional berfungsi mengembangkan kemampuan dan membentuk watak serta peradaban bangsa yang beradab dalam rangka mencerdaskan kehidupan bangsa, bertujuan untuk berkembangnya potensi peserta didik agar menjadi manusia yang beriman dan bertakwa kepada Tuhan Yang Maha Esa, berakhlak mulia, sehat, berilmu, cakap, kreatif serta menjadi warga negara yang demokratis dan bertanggung jawab. Melalui pendidikan, siswa diarahkan untuk dapat mengetahui potensinya dan melakukan sesuatu berdasarkan minat dan bakatnya yang sesuai dengan potensi diri masing-masing.

Sejalan dengan pendapat di atas, Hamalik (2011), menjelaskan bahwa pendidikan merupakan suatu proses dalam rangka memepengaruhi siswa agar dapat menyesuaikan diri sebaik mungkin terhadap lingkungannya dan dengan demikian akan menimbulkan perubahan dalam dirinya yang memungkinkannya untuk dapat berfungsi dalam kehidupan masyarakat. Pengajaran bertugas mengarahkan proses ini agar sasaran dari perubahan dapat tercapai sebagaimana yang di inginkan. Dalam suatu pembelajaran, siswa yang memiliki perbuatan baik, seperti tingkah laku maupun prestasi, harus diberikan penghargaan atau pujian.

Diharapkan dengan penghargaan atau pujian itu siswa akan termotivasi berusaha berbuat yang lebih baik lagi. Misalnya, guru tersenyum atau mengucapkan kata "bagus" kepada siswa yang berpakaian rapih, siswa yang dapat menyelesaikan pekerjaan rumah dengan baik dan benar. Siswa akan merasa puas dengan hasil yang telah dicapai bahkan akan berusaha berbuat yang lebih baik lagi. Dalam kegiatan belajar mengajar, pemberian penguatan sangat penting dalam meningkatkan keefektifan kegiatan pembelajaran.

Menurut pendapat Barnawi dan Arifin (2012), penguatan adalah respon positif dalam pembelajaran yang diberikan guru terhadap perilaku peserta didik dengan tujuan mempertahankan dan meningkatkan perilaku tersebut. Keterampilan memberi 
penguatan mempunyai dua jenis penguatan yaitu penguatan verbal dan non verbal. Strategi merupakan usaha untuk memperoleh kesuksesan dan keberhasilan dalam mencapai tujuan. Dalam dunia pendidikan strategi pembelajaran dapat diartikan sebagai perencanaan yang berisi tentang rangkaian kegiatan yang didesain untuk mencapai tujuan pendidikan tertentu (David, 1976). Seorang guru yang mengharapkan hasil baik dalam proses pembelajaran akan menerapkan suatu strategi agar hasil belajar siswanya mendapat prestasi yang terbaik.

Strategi Pembelajaran adalah suatu kegiatan pembelajaran yang harus dikerjakan guru dan siswa agar tujuan pembelajaran dapat dicapai secara efektif dan efisien. Untuk merealisasikan strategi yang telah ditetapkan maka dipilihlah suatu metode yang akan digunakan untuk mengimplementasikan rencana yang sudah disusun dalam kegiatan nyata agar tujuan yang telah disusun tercapai secara optimal. Keberhasilan implementasi strategi pembelajaran sangat tergantung pada cara guru menggunakan metode pembelajaran.

Metode adalah upaya mengimplementasikan rencana sudah disusun dalam kegiatan nyata agar tujuan yang telah disusun tecapai secara optimal. Pada saat menetapkan strategi yang digunakan, guru harus cermat memilih dan menetapkan metode yang sesuai. Keberhasilan implementasi strategi pembelajaran sangat tergantung pada cara guru menggunakan metode pembelajaran yang tepat yang dapat diterapkan pada proses pembelajaran di kelas. Dalam penelitian ini metode pembelajaran yang digunakan untuk mengimplementasikan dalam pembelajaran adalah model penguatan pemberian pujian.

Pemilihan model pemberian pujian ini digunakan sesuai dengan tujuan penelitian yaitu menanamkan minat belajar siswa, dengan metode pemberian pujian maka siswa akan termotivasi untuk senang belajar dan memberikan perhatian siswa untuk belajar serta mendorong aktivitas siswa sehingga belajarnya lebih terarah. Sedangkan pemberian pujian sebagai salah satu bentuk penguatan (reinforcement) dalam proses belajar mengajar bahasa Indonesia merupakan hal yang sangat diperlukan sehingga dengan penguatan tersebut diharapkan siswa akan terus berbuat yang lebih baik.

Pujian (praise) didefinisikan dalam Webster's Dictionary (2000) sebagai “tindakan mengungkapkan persetujuan atau kekaguman”. Guru menggunakan pujian 
untuk menumbuhkan rasa siswa tentang "harga diri, otonomi, kemandirian, prestasi dan minat untuk belajar". Pujian sering diberikan pada akhir tugas untuk pekerjaan yang dianggap "baik dilakukan" (Hitz). Pujian adalah strategi yang bertujuan untuk mendorong para siswa untuk memantau makna dan mengoreksi diri. Ada beberapa cara yang dapat digunakan dalam merangsang minat siswa dalam belajar yang merupakan motivasi atau dorongan ekstrinsik, diantaranya adalah pemberian hukuman, penghargaan, celaan, persaingan, kompetisi, hadiah dan pemberitahuan tentang kemajuan belajar siswa.

Pemberian hadiah dan pujian merupakan reward atau penghargaan atas perilaku baik yang dilakukan anak. Hal ini sangat diperlukan dalam hubungannya dengan minat dan penerapan disiplin pada anak. Reward atau penghargaan memiliki tiga fungsi penting dalam mengajari anak berperilaku yang disetujui secara sosial. Fungsi yang pertama ialah memiliki nilai pendidikan. Yang kedua, pemberian reward harus menjadi motivasi bagi anak untuk mengulangi perilaku yang diterima oleh lingkungan atau masyarakat. Melalui reward, anak justru akan lebih termotivasi untuk mengulangi perilaku yang memang diharapkan oleh masyarakat. Fungsi yang terakhir ialah untuk memperkuat perilaku yang disetujui secara sosial dan tiadanya penghargaan melemahkan keinginan untuk mengulangi perilaku tersebut. Dengan kata lain, anak akan mengasosiasikan reward dengan perilaku yang disetujui masyarakat.

Berdasarkan pangalaman di lapangan, anak kelas IV di sekolah dasar amat senang apabila usaha belajarnya dihargai dan mendapat pengakuan dari guru, walaupun amat sederhana. Oleh karena itu, para guru jangan terlalu pelit untuk menberikan penghargaan walaupun itu pujian, selama dilakukan dengan memperhatikan waktu dan cara yang tepat. Penghargaan itu sendiri dapat dimaknai sebagai alat pengajaran dalam rangka pengkondisian siswa menjadi senang belajar. Tujuan pemberian penghargaan pujian adalah: a) mendorong siswa agar lebih giat belajar; b) memberi apresiasi atas usaha mereka dan c) menumbuhkan persaingan yang sehat antar siswa untuk meningkatkan prestasi.

Bahasa peserta didik yang kurang percaya diri dalam kemampuan mereka untuk berpartisipasi dengan sukses dalam interaksi lisan sering mendengarkan dalam keheningan sementara yang lain yang bicara. Salah satu cara untuk mendorong peserta didik tersebut untuk mulai berpartisipasi adalah untuk membantu mereka membangun 
suatu persediaan tanggapan minimal yang mereka dapat digunakan dalam berbagai jenis pertukaran..tanggapan tersebut dapat sangat berguna untuk pemula.

Tanggapan minimal dapat diprediksi bahwa peserta percakapan digunakan untuk menunjukkan pemahaman, perjanjian, keraguan, dan tanggapan lain untuk apa yang dikatakan pembicara lain. Memiliki stok tanggapan tersebut memungkinkan pelajar untuk fokus pada apa peserta lain katakan, tanpa harus secara simultan rencana tanggapan.Kelebihan dari pendekatan pembelajaran penguatan pujian dalam proses belajar-mengajar khususnya pembelajaran pendidikan bahasa Indonesia menjadikan anak didik berank dan senang dalm menyatakan pendapat, tanggapan ataupun saran walaupun masih fase belajar. Anak SD belajar lebih menyenangkan tanpa ada rasa ketakutan dalam berargumentasi pada saat belajar.

\section{METODE PENELITIAN}

Metode penelitian menggunakan pendekatan studi pustaka dengan memanfaatkan pegetahuan dan pengalaman mengajar di kelas IV SD Negeri 133 Seluma. Dimana penelitian ini menggambarkan dari hasil pengamatan yang ada di Sekolah Dasar Negeri 133 Seluma. Metode penelitian yang diterapkan dalam penulisan ilmiah ini adalah dengan menggunakan metode deskriptif kualitatif dari hasil pengalaman pembelajaran dan penelitian tindakan di kelas dan studi pustaka dari berbagai sumber. Teknik analisis data menggunakan analisis deksipsi berdasarkan pengamatan proses belajar mengajar yang berlangsung. Teknik pengumpulan data menggunakan observasi, dokumen pembelajaran dan hasil survei kepada siswa dan guru di sekolah. Teknik analisis data dilakukan dengan reduksi data, penyajian data dan verifikasi data sampai penarikan simpulan (Sugiyono. 2010). Sebagai bentuk pertanggungjawaban penelitian, penulis meneliti dan menulis berdasarka kajian keilmuan penelitian.

\section{HASIL PENELITIAN}

Dalam poses pembelajaran di sekolah banyak faktor yang mempengaruhi proses dan hasil pembelajaran yaitu faktor internal dan eksternal. Menurut Iskandarwassid, faktor yang mempengaruhinya: siswa (raw input), faktor lingkungan (environmental 
input), faktor instrument (instrumental input) dan proses belajar mengajar (learningteaching process).

Dari hasil pengalaman mengajar di SD Negeri 133 Seluma, peneliti pernah dan sering menemukan kesulitan untuk mendengar anak dalam berbicara baik itu menyampaikan pendapat atau saran ataupun menyatakan permasalahan. Peneliti sering menemukan yang sering aktif dalam menjawab ataupun menyampaikan pendapat, hanya siswa itu-itu saja. Siswa lebih mononton mendengarkan. Siswa tidak berani dan belum timbul rasa percaya diri. Sehingga peneliti mencari referensi untuk menjadikan siswa akti belajar dan berani menyatakan pendapat ataupun tanggapan di dalam kelas.

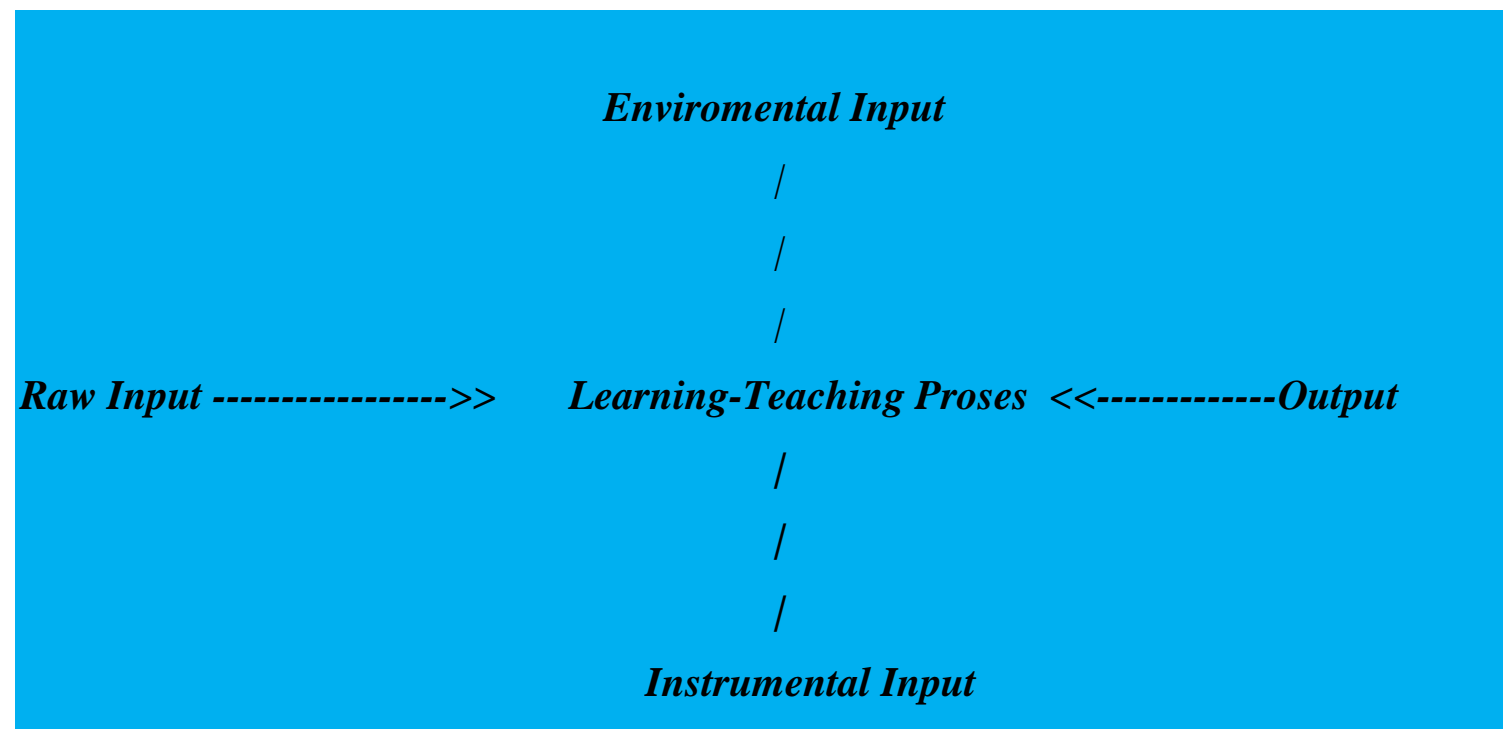

Skema Faktor yang Mempengaruhi Proses BelajarMengajar (Iskandarwassid, 2004)

Berdasarkan pengalaman penulis dalam memberikan pembelajaran di kelas IV, siswa sangat bersemangat jika pembelajaran dikemas dengan semenarik mungkin. Peneliti mengemas pembelajaran menyenangkan dengan pemberian penghargaan melalui reward ucapan langsung atau penguatan verbal ataupun non verbal di kelas IV SD Negeri 133 Seluma. Menurut Usman (2006) penguatan (reinforcement) adalah segala bentuk respons, apakah bersifat verbal ataupun non verbal, yang merupakan bagian dari modifikasi tingkah laku guru terhadap tingkah laku siswa, yang bertujuan untuk memberikan informasi atau umpan balik (feet back) bagi sipenerima (siswa) atas perbuatannya sebagai suatu tindakan dorongan ataupun koreksi. 
Pemberian penguatan yang tepat dapat meningkatkan perhatian dan motivasi belajar siswa. Perhatian siswa yang tinggi terhadap materi yang akan tercermin ketika diadakan penilaian. Nilai yang meningkat menggambarkan prestasi belajar siswa juga meningkat. Ketika hasil belajar siswa meningkat, guru sebagai fasilitator memberikan penguatan dengan berbagai cara yang dapat terus meningkatkan motivasi belajar siswa sehingga prestasi belajar semakin meningkat (Dimyati dan Sujiono, 2009).

Peneliti sering memberikan penghargaan berupa ucapan pujian dilakukan dengan direncanakan terlebih dahulu atau bersifat spontan saja. Hal yang terpenting bahwa setiap siswa yang menunjukkan suatu usaha, maka layak dihargai. Pemberian pujian bagi siswa yang berpatisipasi aktif dalam proses pembelajaran, seperti kata-kata BAGUS! (sambil mengancungkan jempol tangan dengan senyum yang sumringah), KREN SEKALI, TERIMA KASIH SAYANG, LUAR BIASA atau KAMU HEBAT dan lain-lain.

\section{PEMBAHASAN}

Pemberian penghargaan dilakukan dengan berbagai cara dan sesuai kesempatan yang ada. Peneliti membaginya dalam beberapa macam, yakni dalam bentuk ucapan atapun tulisan khusus. Seyogyanya penghargaan ini dapat menjadi kebanggaan siswa akan eksistensi dirinya, yang nantinya meningkatkan rasa percaya diri dan motivasi diri. Ada 3 jenis reward atau penghargaan, yaitu hadiah berupa barang/benda, pujian dan perlakuan istimewa. Apapun jenis reward yang diberikan haruslah disesuaikan dengan tahapan perkembangan anak dan haruslah proporsional.

Sejalan dengan teori Barrnawi dan Arifin (2012), penguatan adalah respon positif dalam pembelajaran yang diberikan guru terhadap perilaku peserta didik dengan tujuan mempertahankan dan meningkatkan perilaku tersebut. Keterampilan memberi penguatan mempunyai dua jenis penguatan yaitu penguatan verbal dan non verbal. Penguatan verbal dinyatakan melalui kata-kata dan kalimat, sedangkan penguatan non verbal dapat diungkapkan dengan berbagai cara seperti gerak isyarat, pendekatan, sentuhan, melalui kegiatan yang menyenangkan, penguatan berupa simbol atau benda, serta penguatan tidak penuh dan penuh.

Penguatan dalam bentuk pemberian penghargaan pujian yang merupakan salah satu keterampilan mengajar yang harus dimiliki oleh seorang guru sehingga dapat 
memberikan suatu dorongan kepada anak didik dalam mengikuti pelajaran. Penguatan yang diberikan oleh guru harus dapat tepat sasaran dan tepat waktu sehingga dapat menjadi pemicu bagi anak didik secara keseluruhan dalam kelas, baik yang menjadi sasaran penguasa maupun bagi teman-temannya.

Tujuan Pemberian penguatan / penghargaan hendaknya selalu mengacu pada prestasi yang ditunjukkan anak didik, baik sewaktu proses pembelajaran berlangsung maupun atas hasil belajar yang dicapai anak didik. Pemberian penguatan tentunya memiliki tujuan tertentu yang mengacu pada peningkatan kemampuan belajar anak didik saat mengikuti pelajaran. Pemberian penguatan pujian merupakan hal penting untuk memotivasi siswa, sehingga perlu kehati-hatian dalam menggunakan pujian. Dan dalam pelaksanaan proses belajar mengajar guru harus menyadari pemberian celaan atau pujian yang berlebihan atau terus menerus akan berpengaruh buruk pada perkembangan jiwa anak.

Sejalan dengan pendapat Menurut pendapat Barnawi dan Arifin (2012), prinsiprinsip yang harus diperhatikan guru saat memberikan penguatan ialah sebagai berikut: a) kehangatan dapat ditunjukkan melalui cara bersikap, tersenyum, melalui suara dan gerak mimik. Misalnya dengan muka atau wajah berseri disertai senyuman, suara yang riang penuh perhatian, b) antusiasme merupakan stimulus untuk meningkatkan perhatian dan motivasi peserta didik. Misalnya, guru memberikan penguatan dengan suara yang lantang dan tatapan mata yang tajam kepada siswa dengan memberikan senyum yang ceria, c) kebermaknaan. Inti dari kebermaknaan ialah peserta didik tahu bahwa dirinya memang layak mendapat penguatan karenatingkah laku dan penampilannya sehingga penguatan tersebut dapat bermakna baginya dan $d$. menghindari penggunaan respon yang negatif. Dari penjelasan di atas, bahwa dengan menitik beratkan pada pencapaian menanamkan minat belajar dengan model pemberian penguatan pujian mempunyai pengaruh dalam proses belajar siswa. Dengan minat yang tinggi maka siswa akan siap mengikuti pelajaran dengan senang hati, penuh perhatian dan lebih terarah beraktifivas dalam proses belajar. 


\section{SIMPULAN}

Dalam poses pembelajaran di sekolah banyak faktor yang mempengaruhi proses dan hasil pembelajaran yaitu faktor internal dan eksternal. Dalam pembelajaran bahasa Indonesia di SD kelas IV ada materi meyampaikan pendapat sanggahan ataupun saran. Dari pengamatan peneliti menunjukkan bahwa siswa sering malu-malu (tidak percaya diri) dalam menyampaikan pendapat ataupun sanggahan. Dengan memberikan penguatan berupa reward melalui bentuk pujian akan melatih anak untuk akti belajar dan siswa mampu menyampaikan pendapat ataupun sanggahan dengan bahasa yang efektif. Berdasarkan pengalaman penulis dalam memberikan pembelajaran di kelas IV, siswa sangat bersemangat jika pembelajaran dikemas dengan semenarik mungkin. Peneliti mengemas pembelajaran menyenangkan dengan pemberian penghargaan melalui reward ucapan langsung atau penguatan verbal ataupun non verbal di kelas IV SD Negeri 133 Seluma.

\section{DAFTAR PUSTAKA}

Barnawi dan Mohammad Arifin. (2012). Etika dan Profesi Kependidikan. Yogyakarta: Ar-Ruzz.

Dimyati, Mudjiono. (2009). Belajar Dan Pembelajaran. Jakarta. PT. Rineka Cipta.

Hamalik. Oemar. (2011). Kurikulum Pendidikan dan Pembelajaran: Jakarta: Bumi Aksara.

Iskandarsassid. (2004). Pengaruh Proses Belajar Mengajar. Jakarta: PT. Gramedia.

J.R. David. (1976). Konsep Penerapan Pembelajaran di Sekolah. Bandung: Nuansa

Sugiyono. (2010). Metode Penelitian. Bandung Alphabeta

Usman, Muh. Uzer. (2006). Menjadi guru Profesional dengan Pemberian Reward. Jakarta: PT Remaja Rosdakarya.

Webster's Dictionary. (2000). Motivasi dan Reward dalam terjemahan. Jakarta: Professional Books. 